\title{
EFFECTIVENESS OF RECURRENT SELECTION FOR IMPROVEMENT OF SOME ECONOMIC CHARACTERS IN EGYPTIAN COTTON
}

\author{
ABOU EL-YAZIED, M.A., Y.A.M. SOLIMAN AND Y.M. EL- MANSY \\ Cotton Research Institute, ARC, Giza, Egypt
}

(Manuscript received 24 November 2013)

\begin{abstract}
Two cycles of recurrent selection for the improvement lint percentage and other associated characters in two cotton crosses were applied at Sakha Agricultural Research Station Kafr El-Sheikh Governorate during six successive seasons (2008 - 2013).The results were as following.

The mean values were increased with first and second cycles of recurrent selection as compared with the basic populations. Genotypic and phenotypic coefficients of variability were larger in $F_{2}$ generation than $F_{3}$ generations and GCV was reduced in later generation (second cycle) indicating that the advanced cycle was more homogenous and uniform than the basic population. In addition, moderate to high estimates of heritability in broad sense were observed for all studied traits in the two populations and increased from $F_{2}$ to $F_{3}$ generations.

There were generally close agreement between predicted and observed responses to selection and predicted over estimated the actual ones for all traits. This suggests that dominance effects were lacking or of relatively with minor importance. Additive genetic effects would appear to predominate in the two populations. Hence, the breeder can depend on the predicted values.

A comparison of direction and magnitude of associations among traits over the two recurrent selection cycles indicated that several new associations in terms of direction and magnitude were observed, these results in newer recombinants which would de due to changes in coupling to repulsion phase linkage. Lint percentage of the second cycle selection exceeded over the base population by $13.3 \%$ and $17.73 \%$ in population I and II, respectively. Response to selection was linear and is predicted to continue at approximately the same rate of gain for an additional cycle.

The correlation responses to selection for lint percentage were observed between some unselected traits measured. As selection increased lint percentage, simultaneous increases were observed for boll weight, fiber length and strength. While, micronair reading showed slight negative desirable change. Generally, recurrent selection has been very successful in increasing the population mean in the desired direction simultaneously for all studied traits without losing variability.
\end{abstract}

\section{INTRODUCTION}

The basic premise of recurrent selection method is to increase the frequency of desirable genes and genetic recombination in a systematic manner to enhance the 
opportunities of identify in superior genotypes in plant population. Success of recurrent selection method is dependent on the original assemblage of genes in breeding populations. If the gene frequency of the trait under selection is different among populations, response to selection may be realized but at different rates and levels. Richmond (1950) first suggested the use of recurrent selection method in cotton breeding in this respect, Opondo and Pathak (1982) mentioned that using recurrent selection was useful increase the frequency of favorable genes so that the populations and population crosses are improved with each selection cycle. Consequently, recombination of desirable characters should be increased.

The principle objectives in the cotton breeding include high lint yield and fiber quality properties. Consequently, plant breeders consider a number of traits during the selection process. Mahdy et al. (1987) compared the efficiency of three selection methods and reported that magnitude of genetic variability persisted after recurrent selection was larger than that after selection index and pedigree selection. In addition, Ahmed et al. (2003) compared actual and predicted genetic selection gains in two cotton crosses. The actual selection gain in general coincided with predicted one for most studied traits in first cross .While, the actual gain values for the second cross were not correlated with predicted values. Abdel-Hafez et al.(2003) estimate the magnitudes of the genetic advance from selection indices in two populations. The genetic gains for lint percentage in population I was large for selection and appeared important in the improvement of lint percentage. The predicted advances from $F_{4}$ generation were higher than those obtained from $F_{3} / F_{4}$. The actual advances were higher than expected for all indices. In the other study, Abd El-Salam (2005) used pedigree selection in three populations and found that the means of $F_{2}$ were lower than $\mathrm{F}_{4}$ for lint percentage and halo length. The phenotypic and genotypic coefficients of variation in $F_{2}$ were higher than those of $F_{3}$ and $F_{4}$, except for halo length and lint percentage in population II, while the coefficient of variations in $F_{4}$ were higher than $\mathrm{F}_{3}$ generation. Heritability ratios were high for lint percentage and halo length for the three populations in different generations.

El-Lawendey et al. (2008) used all possible mating among four $F_{2}$ selections in three populations. The highest predicted genetic advance was achieved for lint yield/ plant, number bolls/plant, lint/seed and seed index in the three populations. High to low genetic advances were found to be associated with high to low values of GCV for most studied characters. In the same time, Abou El-Yazied et al.(2008) used pedigree selection in two populations. The results showed that the means of $F_{2}$ were lower than $F_{3}$ and $F_{4}$, generations for all studied traits except fiber fineness trait .The phenotypic and genotypic coefficients of variability were larger in $F_{2}$ generation than those of the 
succeeding generations for all the studied traits. However, high estimates of heritability in broad sense were observed for all studied traits. The estimates of predicted genetic advance were obviously higher in $F_{4}$ than those in $F_{3}$ generation for most studied traits except for fiber fineness and boll weight in population I as well as fiber strength and boll weight in population II. The same trend was observed for actual gains and also, the selection advance (S.A.\%).

The information about the degree of association among different traits of cotton is of great importance. Hence, cotton breeders are concerned with the total array of all economic characteristics. Thus, it is important to know the change in one trait by selection would affect other economic traits. Therefore, predicted changes as well as observed responses to selection for lint percentage with the unselected traits is worthy of study.

The objective of this investigation was to study the shift in mean performance of lint percentage and other traits from the original population to that of the second selection cycle and to assess the effect of selection on the variability of traits. In addition, to estimate the magnitude of the genetic advance from recurrent selection of lint percentage and its relationship with some unselected traits i. e., boll weight, fiber length, fiber fineness and fiber strength in two cotton population.

\section{MATERIALS AND METHODS}

The genetic materials used in this study included two populations belonging to Gossypium barbadense $L$. The first population was derived from the cross between (Pima high percentage $x$ Suvin) and the second population was derived from the cross between (Pima high percentage x Giza 88). At Sakha Agricultural Research Station Kafr El-Sheikh Governorate during six successive seasons (2008 - 2013).

In 2008 the $F_{2}$ seeds of both populations were sown as well as original parents in non replicated rows $7.0 \mathrm{~m}$., long and $0.65 \mathrm{~m}$. wide, with one skipped row between each two consecutive planted row. Each row contained 10 single plants spaced $70 \mathrm{~cm}$ apart to facilitate self pollinating for each plant. Selection was carried out on $F_{2}$ plants to obtain the desirable individual plants in the field mainly on the basis of plant type, number of retained open bolls and productivity.

The $10 \%$ superior plants for lint percentage as main selected trait were selected as well as, boll weight, fiber length, fiber fineness and fiber strength as associated unselected traits.

In 2009 season the selfed seeds of each $F_{3}$ single plant were planted as in $F_{2}$. The natural seeds of $F_{3}$ plants of each population were evaluated with the two original 
parents in randomized complete block design with three replications. Each plot single row, $4.0 \mathrm{~m}$. in length and $0.65 \mathrm{~m}$. width and $30 \mathrm{~cm}$. between hills. The best ten $F_{3}$ plants according to later traits were saved to produce the second recurrent selection cycle.

In 2010 season selfed seeds of best ten $F_{3}$ plants were sown in a half diallel cross procedure to produce 45 hybrids as possible combination crosses in the two population.

In 2011, Equal amount of the 45 hybrids were mixed and sown in non replicated rows to apply self pollination for producing $F_{2}$ seeds in the two population. In 2012 and 2013, the $F_{2}$ and $F_{3}$ plants of both population were sown as mentioned in first cycle with applied selection $10 \%$ intensity to obtain the best $F_{3}$ families of both populations.

The phenotypic and genotypic coefficients of variance were estimated using the formula developed by Burton (1952):

Phenotypic coefficient of variance $(\mathrm{PCV})=\sigma \mathrm{p} / \overline{\mathrm{X}} \times 100$

Genotypic coefficient of variance $(\mathrm{GCV})=\sigma \mathrm{g} / \overline{\mathrm{X}} \times 100$

Where: $\sigma \mathrm{p}$ and $\sigma \mathrm{g}$ are the standard deviation of phenotypic and genotypic families. $\bar{X}$ is families mean of a trait.

The estimates of broad sense heritability $\left(h^{2} b \%\right)$ were estimated according to the following equation: $\quad h^{2} b \%=\sigma^{2} g / \sigma^{2} p \times 100$

Where:, $V P_{1}$ and $V P_{2}$ the phenotypic variance of, first and second parent variance. $\sigma^{2} P$ and $\sigma^{2} g$ the phenotypic and genotypic, environment variance.

The predicted genetic advance in any traits based on one variable alone was estimated from the following expressions as suggested by Walker (1960) and Miller and Rawlings (1967). $\left(\Delta g x_{w}\right)=K \cdot \sigma^{2} g_{w} / \sigma p_{w}$.

Where, $\mathrm{K}=\mathrm{A}$ selection differential with a value of 1.75 under $10 \%$ selection intensity.

The analyses were made according to Cockerham (1963). The significance between any two different means were tested using the least significant differences values in $F_{3}$ (L.S.D.) at both $5 \%$ and $1 \%$ levels which can be obtained as follows:

$$
\text { L.S.D. }=\mathrm{t}_{0.05} \mathrm{E}_{\mathrm{df}} \times \mathrm{S}_{\mathrm{d}} . \quad \text { L.S.D. }=\mathrm{t}_{0.01} \mathrm{E}_{\mathrm{df}} \times \mathrm{S}_{\mathrm{d}}^{-} . \quad \mathrm{S}_{\mathrm{d}}^{-}=\sqrt{\frac{\mathrm{S}_{1}^{2}}{n 1}+\frac{\mathrm{S}_{2}^{2}}{n 2}}
$$

Where: $n_{1}$ and $n_{2}$ were the number of single plants.

The correlation coefficient between selected and unselected traits was calculated using Minitab 13 computer package.

The change percentage was estimated according to the following equation: Change $\%(S A \%)=$ mean of $C_{1}-$ mean of $C_{0} /$ mean of $C_{0} \times 100$ 


\section{RESULTS AND DISCUSSION}

Recurrent selection in predominantly cross-pollinated crops has been found as an effective system of selection in accumulating favorable alleles at a large number of loci and providing increased opportunities for selection of plants with favorable trait combinations in selected population.

The common experiences of cotton breeders are a reduction in genetic variability in breeding material .This poses a limitation in the choice of parental material in the development of appropriate segregating populations. By conventional breeding methods, maintenance of variability is necessary to sustain the progress in breeding for improved varieties. Thus, recurrent selection method is an important to diversity the genetic variability in conventional program.

Mean performances, phenotypic and genotypic coefficients of variation, heritability, genetic advances and selection advances estimates (Tables 1 and 2) showed that the means of lint percentage, boll weight, fiber length and fiber strength for $F_{2}$ were lower than $F_{3}$ generations of the two populations. While the means of $F_{2}$ were undesirable higher than means of $\mathrm{F}_{3}$ generation for Micronaire reading of the two populations. Similar results were obtained by Abd El-Salam (2005) and Abou El-Yazied et al.(2008)

The results showed phenotypic and genotypic coefficients of variation that was larger in $F_{2}$ generation than $F_{3}$ generations for all studied traits in the two populations where the genotypic coefficient of variation reduced in later generation indicating that the advanced cycles were more homogenous and uniform than the basic population. However, moderate to high estimates of heritability in broad sense were observed for all studied traits in the two populations. These results revealed that the magnitude of the genetic variability persisted in this material was sufficient for providing substantial amount of improvement through the selection of superior progenies and high heritability values are quick and easy to accumulate when using this method of selection. The selection response is determined by the genetic and non genetic variance hence, coefficient of variation is very useful for the study of variation and heritability is the heritable portion of phenotypic variance. It is a good index of the transmission of characters from parents to their offspring (Falconer1981). Further, he suggested that a genetic coefficient of variation together with heritability could give the best indication of the amount of genetic variance to be expected from selection. 
Table 1. Mean performances, phenotypic (PCV) and genotypic (GCV) coefficients of variation, broad sense heritability $\left(h^{2} b\right)$, genetic advances $(\Delta g)$ and selection advances (SA \%) in $F_{2}$ and $F_{3}$ generations through first recurrent selection cycle $\left(C_{1}\right)$ in population I

\begin{tabular}{|c|c|c|c|c|c|c|c|c|c|}
\hline \multirow[b]{2}{*}{ Traits } & \multirow[b]{2}{*}{ Gene. } & \multirow[b]{2}{*}{ Mean $\left(C_{1}\right)$} & \multirow[b]{2}{*}{ PCV\% } & \multirow[b]{2}{*}{ GCV\% } & \multirow{2}{*}{$h_{b}^{2} \%$} & \multicolumn{2}{|c|}{$\Delta g$} & \multirow{2}{*}{$\mathrm{SA} \%$} & \multirow[b]{2}{*}{$\mathrm{C}_{0}$} \\
\hline & & & & & & Pre & Act & & \\
\hline \multirow[t]{2}{*}{ Lint \% } & $\mathrm{F}_{2}$ & $38.39 \pm 0.224$ & 2.9 & 2.0 & 45.9 & 2.09 & 0.90 & 4.28 & 36.75 \\
\hline & $\mathrm{F}_{3}$ & $40.66 \pm 0.225$ & 1.8 & 1.3 & 51.2 & 3.90 & 0.64 & 5.45 & 38.5 \\
\hline \multirow{2}{*}{$\begin{array}{c}\text { Boll } \\
\text { weight }\end{array}$} & $\mathrm{F}_{2}$ & $2.77 \pm 0.035$ & 6.5 & 2.8 & 20.9 & 0.09 & 0.05 & 0.12 & 2.75 \\
\hline & $\mathrm{F}_{3}$ & $3.08 \pm 0.049$ & 5.1 & 2.6 & 25.8 & 0.12 & 0.07 & 4.8 & 2.93 \\
\hline \multirow{2}{*}{$\begin{array}{l}\text { Fibre } \\
\text { length }\end{array}$} & $\mathrm{F}_{2}$ & $31.81 \pm 0.212$ & 3.4 & 3.1 & 80.0 & 2.07 & 1.48 & 1.49 & 31.34 \\
\hline & $\mathrm{F}_{3}$ & $31.45 \pm 0.346$ & 3.2 & 2.8 & 82.0 & 1.69 & 1.57 & 0.83 & 31.23 \\
\hline \multirow{2}{*}{$\begin{array}{l}\text { Mic. } \\
\text { reading }\end{array}$} & $\mathrm{F}_{2}$ & $3.98 \pm 0.07$ & 8.4 & 6.3 & 55.6 & 0.15 & 0.33 & -0.76 & 4.01 \\
\hline & $\mathrm{F}_{3}$ & $4.00 \pm 0.06$ & 4.6 & 3.9 & 73.0 & 0.18 & 0.23 & -2.38 & 4.1 \\
\hline \multirow{2}{*}{$\begin{array}{c}\text { Fiber } \\
\text { strength }\end{array}$} & $\mathrm{F}_{2}$ & $10.48 \pm 0.10$ & 4.9 & 3.9 & 61.3 & 1.0 & 0.55 & 4.5 & 10.01 \\
\hline & $\mathrm{F}_{3}$ & $10.32 \pm 0.12$ & 3.7 & 3.3 & 77.1 & 0.77 & 0.52 & 4.33 & 9.87 \\
\hline
\end{tabular}

$\mathbf{C}_{\mathbf{0}}=$ basic population mean

Table 2. Mean performances, phenotypic (PCV) and genotypic (GCV) coefficients of variation, broad sense heritability $\left(h^{2} b\right)$, genetic advances $(\Delta g)$ and selection advances ( $\mathrm{SA} \%$ ) in $\mathrm{F}_{2}$ and $\mathrm{F}_{3}$ generations through first recurrent selection cycle $\left(C_{1}\right)$ in population II

\begin{tabular}{|c|c|c|c|c|c|c|c|c|c|}
\hline \multirow[b]{2}{*}{ Traits } & \multirow[b]{2}{*}{ Gene. } & \multirow[b]{2}{*}{ Mean $\left(C_{1}\right)$} & \multirow[b]{2}{*}{ PCV\% } & \multirow[b]{2}{*}{ GCV\% } & \multirow{2}{*}{$h_{b}^{2} \%$} & \multicolumn{2}{|c|}{$\Delta \mathrm{g}$} & \multirow[b]{2}{*}{$\mathrm{SA} \%$} & \multirow[b]{2}{*}{$\mathrm{C}_{0}$} \\
\hline & & & & & & Pre & Act & & \\
\hline \multirow[t]{2}{*}{ Lint \% } & $\mathrm{F}_{2}$ & $38.20 \pm 0.211$ & 2.1 & 1.2 & 32.3 & 3.16 & 0.46 & 8.15 & 35.1 \\
\hline & $\mathrm{F}_{3}$ & $39.3 \pm 0.187$ & 1.5 & 1.0 & 44.8 & 2.29 & 0.46 & 3.86 & 38.2 \\
\hline \multirow{2}{*}{$\begin{array}{c}\text { Boll } \\
\text { weight }\end{array}$} & $\mathrm{F}_{2}$ & $2.89 \pm 0.041$ & 5.5 & 4.1 & 54.7 & 0.32 & 0.15 & 5.60 & 2.77 \\
\hline & $\mathrm{F}_{3}$ & $3.0 \pm 0.050$ & 5.1 & 4.0 & 61.4 & 0.33 & 0.17 & 8.1 & 2.77 \\
\hline \multirow{2}{*}{$\begin{array}{l}\text { Fiber } \\
\text { length }\end{array}$} & $\mathrm{F}_{2}$ & $33.59 \pm 0.185$ & 2.1 & 1.6 & 53.4 & 1.98 & 0.67 & 4.19 & 32.2 \\
\hline & $\mathrm{F}_{3}$ & $34.59 \pm 0.213$ & 1.9 & 1.5 & 59.0 & 0.97 & 0.69 & 3.07 & 33.7 \\
\hline \multirow{2}{*}{$\begin{array}{c}\text { Mic. } \\
\text { Reading }\end{array}$} & $\mathrm{F}_{2}$ & $3.93 \pm 0.064$ & 6.3 & 4.2 & 43.0 & 0.19 & 0.10 & 1.98 & 3.85 \\
\hline & $\mathrm{F}_{3}$ & $3.73 \pm 0.054$ & 4.6 & 3.1 & 47.9 & 0.46 & 0.14 & -4.68 & 3.9 \\
\hline \multirow{2}{*}{ Fiber strength } & $\mathrm{F}_{2}$ & $10.38 \pm 0.091$ & 3.40 & 2.8 & 66.7 & 0.64 & 0.41 & 1.72 & 10.2 \\
\hline & $\mathrm{F}_{3}$ & $10.35 \pm 0.067$ & 2.0 & 1.3 & 70.5 & 0.90 & 0.14 & 2.54 & 10.08 \\
\hline
\end{tabular}

$\mathbf{C}_{\mathbf{0}}=$ basic population mean

In addition, Shaheen et al. (2000) found that heritability for $F_{2}$ generation was lower than $F_{3}$ for lint percentage and fiber length in three populations. Also, Gooda 
(2006) studied improvement in two populations and found that, P.C.V. and G.C.V. were decreased from $F_{2}$ to $F_{3}$ generations for all studied traits and heritability estimates in broad sense increased from $F_{2}$ to $F_{3}$ generation for the same traits. Improvement of halo length, fiber length at $2.5 \%$, Pressley index and Micronaire value were achieved by using direct phenotypic selection for seed cotton yield, lint yield, boll weight, seed index and lint index.

Comparing the predicted gains with the actual ones, it could be noticed that the predicted surpassed the actual one for all studied traits in the two populations. This may be due to the unfavorable environmental conditions which inhibitor genes which controlled these quantitative traits as well as, high estimates values of heritability in broad sense were observed in unselected traits in the two populations. Similar results were obtained by El Lawendy (2003) who mentioned that large discrepancies were observed between predicted and realized gains because genotypic variances and covariance's used to calculate predicted gains were likely biased by certain genotypic $x$ environment interaction.

Also, selection advance (SA \%) was high for the selected trait, lint percentage in the two populations and some unselected traits i.e., boll weight and fiber strength in population I as well as, boll weight and fiber length in population II. These indicated that selection for lint percentage in the two populations was effective and sufficient to improve lint percentage and subsequently improvement some unselected traits. Hence, the highest values of selection advances compared with unselected generation mean traits (the check) indicating that selection procedures applied were effective and successful for selecting the best families within the two populations with respect to these traits.

Generally, the predicted and actual gains obtained from recurrent selection were nearly similar in both populations. Improvement in lint percentage, boll weight and fiber quality could be due to high selection intensity, genotypic coefficient of variance and heritability. These three factors play a major role in genetic advances in the two populations. Similar results were obtained by Ahmed et al. (2003),Abdel-Hafez et al.(2003) , El-Lawendey et al. (2008) and Abou El-Yazied et al.(2008).

The results of mean performance of F3 selected families for five traits on the first recurrent selection cycle in the two population using L.S.D. are presented in Table 3 and 4 . The best ten families in each population were chosen from $F_{3}$ generation for five phenotypic selection traits compared with their respective parents for the selected traits by using L.S.D.,. The most superior families showed significant and highly significant differences for lint percentage trait, special families numbers $8,11,20,31$, and 34 in population I and families numbers 4, 9, 21 and 25 in population 
II which showed best highly significant values for most studied traits in the two population.

The $F_{3}$ generation in the two populations for the first recurrent selection cycle contains amounts of genetic variation to get up best results of gains from using phenotypic selection and response of genetic advance in lint percentage through another recurrent selection cycle through hybridization procedure to produce 45 hybrids as possible combination crosses between the best ten selected families in the two population. Similar results were obtained by Abd El-Salam (2005).

Table 3. Mean performance of $F_{3}$ selected families for five traits on first recurrent Selection cycle $\left(C_{1}\right)$ in population I comparative with mean it's parents

\begin{tabular}{|c|c|c|c|c|c|}
\hline $\begin{array}{l}\mathrm{F}_{3} \text { selec. } \\
\text { Families }\end{array}$ & $\begin{array}{c}\text { Lint } \\
\text { percentage }\end{array}$ & $\begin{array}{c}\text { Boll } \\
\text { weight }\end{array}$ & $\begin{array}{l}\text { Fiber } \\
\text { length }\end{array}$ & $\begin{array}{c}\text { Fiber } \\
\text { fineness }\end{array}$ & $\begin{array}{c}\text { Fiber } \\
\text { strength }\end{array}$ \\
\hline 3 & $39.9+$ & $2.9++$ & 31.0 & 4.1 & 10.1 \\
\hline $8^{*}$ & $43.0++$ & $3.3++$ & 30.3 & 4.0 & $11.3++$ \\
\hline $11^{*}$ & $42.2++$ & $3.1++$ & 30.6 & 4.1 & $10.5++$ \\
\hline 13 & $40.2++$ & $3.2++$ & 31.2 & 4.0 & 10.0 \\
\hline 15 & $40.1++$ & $3.0++$ & 32.2 & $3.7+$ & 10.0 \\
\hline 17 & $40.6++$ & $3.0++$ & 30.7 & 4.0 & 10.2 \\
\hline $20 *$ & $41.2++$ & $3.4++$ & 33.0 & $3.6++$ & 10.1 \\
\hline 22 & 39.1 & $2.9++$ & 33.1 & 4.0 & 10.1 \\
\hline $31^{*}$ & $42.9++$ & $3.2++$ & 31.4 & 4.1 & $10.5++$ \\
\hline $34 *$ & $41.0++$ & $3.0++$ & 31.1 & 4.2 & $10.5++$ \\
\hline $\bar{X}$ & 40.83 & 3.08 & 31.57 & 4.0 & 10.32 \\
\hline P1 (PHP) & 38.31 & 2.55 & 34.3 & 3.9 & 10.15 \\
\hline P2(Suven) & 35.89 & 2.43 & 31.16 & 4.11 & 9.9 \\
\hline L.S.D 0.05 & 0.91 & 0.19 & 0.53 & 0.16 & 0.24 \\
\hline L.S.D 0.01 & 1.28 & 0.27 & 0.75 & 0.22 & 0.34 \\
\hline
\end{tabular}

$*$, $* *$ Significant and highly significant at $5 \%$ and $1 \%$ levels, respectively.

PHP = Pima high percentage 
Table 4. Mean performance of $F_{3}$ selected families for five traits on first recurrent Selection cycle $\left(\mathrm{C}_{1}\right)$ in population II comparative with mean it's parents

\begin{tabular}{|c|c|c|c|c|c|}
\hline $\begin{array}{c}\mathrm{F}_{3} \text { selec. } \\
\text { Families }\end{array}$ & $\begin{array}{c}\text { Lint } \\
\text { percentage }\end{array}$ & $\begin{array}{c}\text { Boll } \\
\text { weight }\end{array}$ & $\begin{array}{c}\text { Fiber } \\
\text { length }\end{array}$ & $\begin{array}{c}\text { Fiber } \\
\text { fineness }\end{array}$ & $\begin{array}{c}\text { Fiber } \\
\text { strength }\end{array}$ \\
\hline 2 & $39.4+$ & 3.0 & 33.9 & 4.2 & 10.1 \\
\hline $4 *$ & $40.0++$ & 3.0 & 35.7 & $3.6++$ & $11.1+$ \\
\hline 5 & 38.7 & 3.1 & 34.6 & 4.1 & 10.3 \\
\hline $9 *$ & $40.1++$ & 3.1 & 34.9 & 3.8 & 10.6 \\
\hline 11 & 38.6 & 3.2 & 34.9 & 4.5 & 10.2 \\
\hline 14 & 38.4 & 2.9 & 33.6 & 4.3 & 10.0 \\
\hline 16 & 39.0 & 2.9 & 34.5 & 4.2 & 10.1 \\
\hline 17 & 39.3 & 2.8 & 34.8 & 4.2 & 10.5 \\
\hline $21^{*}$ & $39.6+$ & 2.9 & 33.4 & 4.2 & 10.8 \\
\hline $25 *$ & $39.7+$ & 2.8 & 33.5 & 4.2 & 10.5 \\
\hline $\bar{X}$ & 39.3 & 3.1 & 34.59 & 4.13 & 10.35 \\
\hline P1 (PHP) & 38.31 & 2.55 & 34.3 & 3.9 & 10.15 \\
\hline P2(Giza 88$)$ & 37.8 & 3.2 & 35.22 & 4.0 & 10.81 \\
\hline L.S.D 0.05 & 1.18 & 0.18 & 0.58 & 0.18 & 0.25 \\
\hline L.S.D 0.01 & 1.66 & 0.26 & 0.81 & 0.26 & 0.35 \\
\hline
\end{tabular}

$*$,** Significant and highly significant at $5 \%$ and $1 \%$ levels, respectively.

PHP = Pima high percentage

The mean performances, phenotypic and genotypic coefficients of variation, heritability, genetic advances and selection advances estimates in Tables 5 and 6 showed the same trend as in first selection cycle with a further boost on mean performances in second cycle for all studied traits in the two populations. The results for lint percentage and other correlated trait clearly indicated that there has been a positive shift in the population means for both populations. 
Table 5. Mean performances, phenotypic (PCV) and genotypic (GCV) coefficient of variation and broad sense heritability $\left(h^{2} b\right)$, genetic advances $(\Delta g)$ and selection advances (SA \%) in $F_{2}$ and $F_{3}$ generations through second recurrent selection cycle $\left(\mathrm{C}_{2}\right)$ in population I

\begin{tabular}{|c|c|c|c|c|c|c|c|c|c|}
\hline \multirow[b]{2}{*}{ Traits } & \multirow[b]{2}{*}{ Gene. } & \multirow[b]{2}{*}{ Mean $\left(C_{2}\right)$} & \multirow[b]{2}{*}{ PCV\% } & \multirow[b]{2}{*}{ GCV\% } & \multirow{2}{*}{$h_{b}^{2} \%$} & \multicolumn{2}{|c|}{$\Delta \mathrm{g}$} & \multirow[b]{2}{*}{$\mathrm{SA} \%$} & \multirow[b]{2}{*}{$\mathrm{C}_{0}$} \\
\hline & & & & & & Pre & Act & & \\
\hline \multirow[t]{2}{*}{ Lint \% } & $\mathrm{F}_{2}$ & $40.89 \pm 0.161$ & 1.7 & 1.2 & 57.0 & 2.47 & 0.65 & 5.05 & 38.79 \\
\hline & $\mathrm{F}_{3}$ & $41.27 \pm 0.142$ & 1.3 & 1.1 & 66.7 & 2.64 & 0.67 & 5.17 & 39.15 \\
\hline \multirow{2}{*}{$\begin{array}{c}\text { Boll } \\
\text { weight }\end{array}$} & $\mathrm{F}_{2}$ & $3.11 \pm 0.042$ & 5.8 & 3.3 & 33.6 & 0.47 & 0.11 & 4.31 & 2.99 \\
\hline & $\mathrm{F}_{3}$ & $3.17 \pm 0.040$ & 4.0 & 2.8 & 37.2 & 0.15 & 0.08 & 3.14 & 3.09 \\
\hline \multirow{2}{*}{$\begin{array}{l}\text { Fiber } \\
\text { length }\end{array}$} & $\mathrm{F}_{2}$ & $33.63 \pm 0.189$ & 1.8 & 1.2 & 36.5 & 1.55 & 0.45 & 2.47 & 32.72 \\
\hline & $\mathrm{F}_{3}$ & $34.12 \pm 0.168$ & 1.6 & 1.0 & 40.0 & 0.67 & 0.39 & 0.80 & 33.84 \\
\hline \multirow{2}{*}{$\begin{array}{c}\text { Mic. } \\
\text { reading }\end{array}$} & $\mathrm{F}_{2}$ & $4.13 \pm 0.044$ & 4.5 & 3.2 & 51.1 & 0.37 & 0.17 & -3.32 & 4.28 \\
\hline & $\mathrm{F}_{3}$ & $3.97 \pm 0.97$ & 4.2 & 3.1 & 59.0 & 0.36 & 0.17 & 0.62 & 3.95 \\
\hline \multirow{2}{*}{$\begin{array}{c}\text { Fiber } \\
\text { strength }\end{array}$} & $\mathrm{F}_{2}$ & $10.02 \pm 0.062$ & 2.6 & 2.2 & 72.8 & 1.16 & 0.34 & 3.90 & 9.62 \\
\hline & $\mathrm{F}_{3}$ & $10.34 \pm 0.066$ & 2.5 & 2.1 & 76.0 & 1.12 & 0.35 & 6.18 & 9.07 \\
\hline
\end{tabular}

$\mathbf{C}_{\mathbf{0}}=$ basic population mean

Table 6. Mean performances, phenotypic (PCV) and genotypic (GCV) coefficients of variation and broad sense heritability $\left(h^{2} b\right)$, genetic advances $(\Delta g)$ and selection advances (SA \%) in $F_{2}$ and $F_{3}$ generations through second recurrent selection cycle $\left(\mathrm{C}_{2}\right)$ in population II

\begin{tabular}{|c|c|c|c|c|c|c|c|c|c|}
\hline \multirow[b]{2}{*}{ Traits } & \multirow[b]{2}{*}{ Gene. } & \multirow[b]{2}{*}{ Mean $\left(C_{2}\right)$} & \multirow[b]{2}{*}{ PCV\% } & \multirow[b]{2}{*}{ GCV\% } & \multirow{2}{*}{$h_{b}^{2} \%$} & \multicolumn{2}{|c|}{$\Delta g$} & \multirow[b]{2}{*}{$\mathrm{SA} \%$} & \multirow[b]{2}{*}{$\mathrm{C}_{0}$} \\
\hline & & & & & & Pre & Act & & \\
\hline \multirow[t]{2}{*}{ Lint $\%$} & $\mathrm{~F}_{2}$ & $40.83 \pm 0.147$ & 1.7 & 1.4 & 68.7 & 3.51 & 0.83 & 5.93 & 38.36 \\
\hline & $\mathrm{F}_{3}$ & $41.57 \pm 0.152$ & 1.5 & 1.3 & 72.2 & 3.17 & 0.79 & 6.56 & 38.83 \\
\hline \multirow{2}{*}{$\begin{array}{c}\text { Boll } \\
\text { weight }\end{array}$} & $\mathrm{F}_{2}$ & $3.27 \pm 0.035$ & 5.0 & 4.0 & 63.7 & 0.30 & 0.18 & 4.15 & 3.14 \\
\hline & $\mathrm{F}_{3}$ & $3.16 \pm 0.037$ & 4.8 & 3.9 & 66.4 & 0.38 & 0.17 & 1.53 & 3.10 \\
\hline \multirow{2}{*}{$\begin{array}{l}\text { Fiber } \\
\text { length } \\
\end{array}$} & $F_{2}$ & $34.4 \pm 0.178$ & 2.4 & 2.0 & 64.5 & 2.27 & 0.94 & 2.14 & 33.66 \\
\hline & $\mathrm{F}_{3}$ & $34.65 \pm 0.182$ & 2.2 & 1.8 & 66.6 & 1.29 & 0.87 & 0.64 & 34.45 \\
\hline \multirow{2}{*}{$\begin{array}{l}\text { Mic. } \\
\text { reading }\end{array}$} & $\mathrm{F}_{2}$ & $4.22 \pm 0.041$ & 4.9 & 2.8 & 32.4 & 0.24 & 0.11 & -2.32 & 4.34 \\
\hline & $\mathrm{F}_{3}$ & $3.7 \pm 0.042$ & 4.7 & 2.8 & 35.2 & 0.19 & 0.11 & -2.60 & 3.81 \\
\hline \multirow{2}{*}{$\begin{array}{c}\text { Fiber } \\
\text { strength }\end{array}$} & $\mathrm{F}_{2}$ & $10.25 \pm 0.093$ & 4.2 & 3.6 & 74.6 & 1.14 & 0.56 & 2.97 & 9.96 \\
\hline & $\mathrm{F}_{3}$ & $10.42 \pm 0.095$ & 2.7 & 2.0 & 75.6 & 0.80 & 0.28 & 4.05 & 10.0 \\
\hline
\end{tabular}

$\mathbf{C}_{\mathbf{0}}=$ basic population mean 
The results of mean performance of $F_{3}$ selected families for five traits in second recurrent selection cycle for the two population using L.S.D. are presented in Table 7and 8.The best eighteen families in population I were chosen from $\mathrm{F}_{3}$ generation for five phenotypic selection traits compared with mean it's parents for selected traits by using L.S.D., the best families showed significant and highly significant differences for lint percentage trait, especially families numbers 70,80,120,148and 165 in population I. While, seventeen best families in population II especially families numbers 28, 83, 88, 121, 137, 138 and 163 showed highly significant values for most studied traits .

The superior of such families as a result of using recurrent selection in each population may be due to increased in the frequencies of favorable genes so that the populations and population crosses are improved with each selection cycle. In this phase recombination of desirable traits should be increased Opondo and Pathak (1982).

Table 7. Mean performance of $F_{3}$ selected families for five traits on second recurrent selection cycle $\left(\mathrm{C}_{2}\right)$ in population I comparative with mean it's parents

\begin{tabular}{|c|c|c|c|c|c|}
\hline $\begin{array}{l}F_{3} \text { selec. } \\
\text { Families }\end{array}$ & $\begin{array}{c}\text { Lint } \\
\text { percentage }\end{array}$ & $\begin{array}{c}\text { Boll } \\
\text { weight }\end{array}$ & $\begin{array}{l}\text { Fiber } \\
\text { length }\end{array}$ & $\begin{array}{c}\text { Fiber } \\
\text { fineness }\end{array}$ & $\begin{array}{c}\text { Fiber } \\
\text { strength }\end{array}$ \\
\hline 26 & $40.9 * *$ & $3.1 * *$ & 33.8 & 4.0 & 9.9 \\
\hline 48 & $41.1 * *$ & $3.2^{* *}$ & 34.2 & 4.0 & 10 \\
\hline 59 & $40.5 * *$ & $3.2^{* *}$ & 34.3 & 4.0 & 10.4 \\
\hline $70 *$ & $41.9 * *$ & $3.3 * *$ & 34.6 & $3.6^{*}$ & $10.8^{* *}$ \\
\hline $80 *$ & $41.6 * *$ & $3.1^{* *}$ & 34.4 & $3.7 *$ & $10.7 * *$ \\
\hline 92 & $41.1^{* *}$ & $3.2^{* *}$ & 34.4 & 4.1 & 10.2 \\
\hline 98 & $41.0 * *$ & 2.9 & 34.2 & 4.0 & 10.4 \\
\hline $120 *$ & $41.8^{* *}$ & $3.4 * *$ & 34.7 & $3.6+$ & $10.7 * *$ \\
\hline 165 & $40.6 * *$ & $3.2^{* *}$ & 33.5 & 4.1 & 9.9 \\
\hline $148 *$ & $42.4 * *$ & $3.4 * *$ & 34.8 & $3.6+$ & $10.5^{*}$ \\
\hline 151 & $41.5^{* *}$ & $3.3^{* *}$ & 33.1 & 4.0 & 10.0 \\
\hline $165 *$ & $41.9 * *$ & $3.4 * *$ & 34.5 & 3.9 & $10.6 * *$ \\
\hline 166 & $41.3 * *$ & $3.2 * *$ & 33.6 & 4.0 & 9.8 \\
\hline 169 & $40.7 * *$ & $3.0+$ & 34.6 & 4.0 & 10.4 \\
\hline 170 & $41.6 * *$ & $3.2^{* *}$ & 34.2 & 4.0 & $10.5^{*}$ \\
\hline 171 & $41.6 * *$ & $3.2 * *$ & 33.3 & 4.2 & 9.8 \\
\hline 183 & $40.5 * *$ & $3.1 * *$ & 34.7 & 4.0 & $10.5^{*}$ \\
\hline 189 & $40.7 * *$ & $3.2^{* *}$ & 33.2 & 4.0 & 10.0 \\
\hline $\bar{X}$ & 41.27 & 3.17 & 34.12 & 3.93 & 10.28 \\
\hline $\mathrm{P} 1$ (PHP) & 38.31 & 2.55 & 34.3 & 3.9 & 10.11 \\
\hline P2(Suven) & 35.89 & 2.4 & 31.06 & 4.01 & 9.8 \\
\hline L.S.D 0.05 & 0.94 & 0.25 & 0.46 & 0.20 & 0.32 \\
\hline L.S.D 0.01 & 1.33 & 0.36 & 0.64 & 0.29 & 0.45 \\
\hline
\end{tabular}


Table 8. Mean performance of $F_{3}$ selected families for five traits on second recurrent selection cycle $\left(C_{2}\right)$ in population II comparative with mean it's parents

\begin{tabular}{|c|c|c|c|c|c|}
\hline $\begin{array}{l}\mathrm{F}_{3} \text { selec. } \\
\text { Families }\end{array}$ & $\begin{array}{c}\text { Lint } \\
\text { percentage }\end{array}$ & $\begin{array}{c}\text { Boll } \\
\text { weight }\end{array}$ & $\begin{array}{l}\text { Fiber } \\
\text { length }\end{array}$ & $\begin{array}{c}\text { Fiber } \\
\text { fineness }\end{array}$ & $\begin{array}{c}\text { Fiber } \\
\text { strength }\end{array}$ \\
\hline 23 & $41.4 * *$ & 3.1 & 33.7 & 3.9 & 10.5 \\
\hline 25 & $40.1 * *$ & 2.9 & 34.1 & 4.0 & 10.5 \\
\hline 26 & $40.8^{* *}$ & 3.1 & 34.1 & 3.8 & 10.1 \\
\hline $28^{*}$ & $42.4 * *$ & 3.13 & $35.8^{*}$ & $3.5^{*}$ & 10.7 \\
\hline 29 & $40.5 * *$ & 3.1 & 34.5 & $3.5^{*}$ & 10.0 \\
\hline 30 & $41.8^{* *}$ & 3.0 & 33.4 & 3.9 & 10.2 \\
\hline 42 & $41.1 * *$ & 3.0 & 35.0 & $3.7 *$ & 10.7 \\
\hline 44 & $40.5 * *$ & 2.9 & 33.4 & 4.0 & 10.2 \\
\hline 55 & $40.9 * *$ & 3.2 & 34.2 & 3.9 & 10.4 \\
\hline $83 *$ & $43.4 * *$ & $3.6++$ & $35.9 *$ & $3.6^{*}$ & 10.8 \\
\hline $88^{*}$ & $42.1 * *$ & 3.2 & 35.2 & $3.5^{*}$ & 10.5 \\
\hline $121 *$ & $42.9 * *$ & $3.5++$ & $35.9 *$ & $3.6^{*}$ & 10.6 \\
\hline 122 & $41.5^{* *}$ & 3.1 & 34.1 & $3.7^{*}$ & 10.2 \\
\hline $137 *$ & $42.3 * *$ & 3.2 & 34.6 & $3.4 * *$ & 10.5 \\
\hline $138^{*}$ & $42.2 * *$ & 3.3 & 35.2 & $3.6+$ & 10.5 \\
\hline $163 *$ & $42.0 * *$ & 3.3 & $36.2 * *$ & $3.3 * *$ & 10.8 \\
\hline 167 & $40.8^{* *}$ & 3.0 & 34.1 & 3.9 & 10.2 \\
\hline $\bar{X}$ & 41.57 & 3.16 & 34.65 & 3.7 & 10.42 \\
\hline $\mathrm{P} 1(\mathrm{PHP})$ & 38.31 & 2.5 & 34.3 & 3.9 & 10.11 \\
\hline P2(Giza 88) & 37.7 & 3.1 & 35.2 & 3.98 & 10.76 \\
\hline L.S.D 0.05 & 1.21 & 0.26 & 0.55 & 0.18 & 0.22 \\
\hline L.S.D 0.01 & 1.70 & 0.36 & 0.78 & 0.28 & 0.30 \\
\hline
\end{tabular}

$*, * *$ Significant and highly significant at $5 \%$ and $1 \%$ levels, respectively.

$\mathrm{PHP}=$ Pima high percentage

The coefficient of correlation provides a measure of the genotypic association between pairs of traits to identify the traits which could be used as indicator for improvement of other traits through the selection programs. Table 9 revealed that the correlation between lint percentage (selected trait) and the other unselected traits in $\mathrm{F}_{3}$ selected families in first cycle was significant for boll weight in population I. Also, positive and highly significant correlation relative to fiber strength in the two 
populations. While, negative and desirable highly significant association with fiber fineness were observed in population II only. In spite of, second recurrent selection cycle the lint percentage showed positive and highly significant correlation with boll weight in both population and fiber length in population II only as well as, positive significant correlation for fiber strength in both populations. On the other hand, negative and desirable highly significant correlation observed for fiber fineness in population I and significant correlation with same trait in population II.

A comparison of direction and magnitude of association among traits in the two recurrent selection cycles Table 9 indicate that, several new associations in terms of direction and magnitude of association was observed. For example association of lint percentage with fiber length ( -0.51 and 0.21$)$ in population I and II respectively in the first cycle but changed to positive 0.47 and significant $0.71^{* *}$ in the second cycle .Also, between fiber length with each of fiber fineness and fiber strength, the associations were changed in sign and magnitude. It was thus evident that the reshuffling of genes responsible for correlations amongst some characters resulted in newer recombinants, which presumably, were due to changes a coupling to repulsion phase linkages. Abdel Salam et. al.(2013) found that the correlation between seed index and lint percentage was negative and significant in pedigree selection but it was changed to non significant in recurrent selection. This changed in correlation was due to the changes in relationship by random intermatting.

Table 9. Correlation coefficient between selected and unselected traits through the two recurrent selection cycles in the two populations

\begin{tabular}{|c|c|c|c|c|c|c|c|c|c|}
\hline Population & \multicolumn{5}{|c|}{ Population I $\mathrm{F}_{3}$ selected families } & \multicolumn{4}{|c|}{ Population II $\mathrm{F}_{3}$ selected families } \\
\hline Selection & Traits & $\mathrm{L} \%$ & B.W & F.L & F.F & $\mathrm{L} \%$ & B.W & F.L & F.F \\
\hline \multirow{4}{*}{ 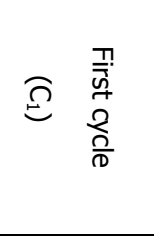 } & B.W & $0.65^{*}$ & & & & -0.16 & & & \\
\hline & F.L & -0.51 & -0.01 & & & 0.21 & 0.48 & & \\
\hline & F.F & 0.31 & -0.32 & $-0.69^{*}$ & & $-0.74^{* *}$ & -0.07 & -0.55 & \\
\hline & F.S & $0.79^{* *}$ & 0.38 & -0.58 & 0.48 & $0.78^{* *}$ & -0.09 & 0.34 & $-0.69^{*}$ \\
\hline \multirow{4}{*}{ 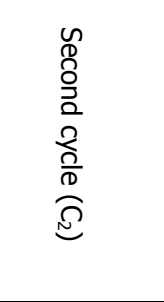 } & B.W & $0.83^{* *}$ & & & & $0.84^{* *}$ & & & \\
\hline & F.L & 0.47 & 0.21 & & & $0.71^{* *}$ & $0.75^{* *}$ & & \\
\hline & F.F & $-0.76^{* *}$ & $-0.65^{*}$ & $-0.69^{*}$ & & $-0.61^{*}$ & $-0.58^{*}$ & $-0.79^{* *}$ & \\
\hline & F.S & $0.62^{*}$ & 0.41 & $0.82^{* *}$ & $\begin{array}{l}- \\
0.75^{* *}\end{array}$ & $0.64^{*}$ & $0.56^{*}$ & $0.71^{* *}$ & -0.44 \\
\hline
\end{tabular}

$*, * *$ Significant and highly significant at $5 \%$ and $1 \%$ levels, respectively 
The responses to selection were relatively good, having regard to the selection pressures used. Table 10 showed the superiority of advanced cycles (SA\%) for studied traits in the two recurrent selection cycles over the base population in the two populations. The superiority of advanced cycles for lint percentage in F3 selected families (second recurrent selection cycle) exceeded the base population (F2 in first recurrent selection cycle) by $13.13 \%$ and $17.73 \%$ in population I and II respectively. simultaneous increases were observed for unselected traits, boll weight by $14.92 \%$ and $13.63 \%$, fiber length by $8.84 \%$ and $7.59 \%$ and fiber strength by $3.28 \%$ and $2.14 \%$. While, Micronair reading showed slight negative desirable change by $-1.0 \%$ and $-3.92 \%$ in population I and II respectively. Hence, response to selection was linear and is predicted to continue at approximately the same rate of gain for an additional cycle. The superiority of advanced cycles for lint percentage and other studied traits was further substantiating from the comparisons of individual S1 progeny. These results clearly demonstrate that with increase in the mean of lint percentage of the two populations, the opportunity of deriving high lint percentage lines is also attainable. These results are in accordance with those obtained by Eberhart (1972) who reported that the improvement in breeding populations results in parallel improvement in the lines derived from the population at the end of each selection cycle. Based on, the observation from these results it can concluded that recurrent selection in the two populations has been very successful in increasing the population mean in the desired direction simultaneously for all traits without losing variability.

Table 10. The superiority of advanced cycles (SA\%) for studied traits in the two Recurrent selection cycles over the base population in the two populations

\begin{tabular}{|c|c|c|c|c|c|c|c|}
\hline \multirow{2}{*}{ Traits } & \multirow[t]{2}{*}{ Cycle } & \multirow{2}{*}{ Pop.I } & \multicolumn{2}{|c|}{ Change \%(SA\%) } & \multirow{2}{*}{ Pop.II } & \multicolumn{2}{|c|}{ Change \%(SA\%) } \\
\hline & & & Over cycle & Cumulative & & Over cycle & Cumulative \\
\hline \multirow{3}{*}{ Lint \% } & $\mathrm{C}_{0}$ & 36.75 & - & - & 35.1 & - & - \\
\hline & $\mathrm{C}_{1}$ & 40.66 & 10.63 & 10.63 & 39.3 & 11.96 & 11.96 \\
\hline & $\mathrm{C}_{2}$ & 41.27 & 10.5 & 13. 13 & 41.57 & 5.77 & 17.73 \\
\hline \multirow{3}{*}{ Boll weight } & $\mathrm{C}_{0}$ & 2.75 & - & - & 2.77 & - & - \\
\hline & $\mathrm{C}_{1}$ & 3.08 & 14.01 & 12.0 & 3.0 & 8.30 & 8.30 \\
\hline & $\mathrm{C}_{2}$ & 3.17 & 2.92 & 14.92 & 3.16 & 5.33 & 13.63 \\
\hline \multirow{3}{*}{ Fiber length } & $\mathrm{C}_{0}$ & 31.34 & - & - & 32.2 & - & - \\
\hline & $\mathrm{C}_{1}$ & 31.35 & 0.35 & 0.35 & 34.59 & 7.42 & 7.42 \\
\hline & $\mathrm{C}_{2}$ & 34.12 & 8.48 & 8.84 & 34.65 & 0.17 & 7.59 \\
\hline \multirow{3}{*}{ Mic. reading } & $\mathrm{C}_{0}$ & 4.01 & - & - & 3.85 & - & - \\
\hline & $\mathrm{C}_{1}$ & 4.0 & -0.25 & -0.25 & 3.73 & -3.12 & -3.12 \\
\hline & $\mathrm{C}_{2}$ & 3.97 & -0.75 & -1.0 & 3.7 & -0.80 & -3.92 \\
\hline \multirow{3}{*}{ Fiber strength } & $\mathrm{C}_{0}$ & 10.01 & - & - & 10.2 & - & - \\
\hline & $\mathrm{C}_{1}$ & 10.32 & 3.09 & 3.09 & 10.35 & 1.47 & 1.47 \\
\hline & $\mathrm{C}_{2}$ & 10.34 & 0.19 & 3.28 & 10.42 & 0.67 & 2.14 \\
\hline
\end{tabular}

$\mathbf{C}_{\mathbf{0}}=$ basic population mea, $\mathbf{C}_{\mathbf{1}}=$ First selection cycle mean, $\mathbf{C}_{\mathbf{2}}=$ Second selection cycle mean 


\section{REFERENCES}

1. Abd El-Salam, M.E. 2005. Studies on breeding and maintenance of cotton varieties (G. barbadense L.).Ph.D.Thesis Fac.of Agric.,KafrEl-Sheikh, Tanta Univ., Egypt.

2. Abd El-Salam,M.E.,B.M.Ramadan and Y.M. EL Mansy. 2013. Relative effectiveness of pedigree and recurrent eslection in cotton.2ad Alexandria International cotton Conference. 10-11 April 2013.

3. Abdel-Hafez,A.G.,M.Sh.El-Keredy,A.F.H.El-Okia,H.A. El-Harouni and B.M, Ramadan. 2003. Improvement of earliness index, boll weight and lint percentage using indirect selection in Egyptian Cotton. Egy. J. plant breed. 7(1):512-533.

4. Abou El-Yazied,M.A.,Allam, M.A.M. and Soliman, Y.A.M. 2008. Genetic

5. improvement of some fiber quality and yield components in two extra long

6. cotton crosses. J. Agric. Sci. Mansoura Univ.,33 (2):1203-1210.

7. Ahmed M.F., A.M. Esmail, A.M. El-Marakby and M.A. Rashed 2003. Actual versus predicted genetic selection gains for some agronomic traits and identifying molecular markers assistant to selection for earliness in cotton crosses. Egy. J. plant breed. 7(1):419-438.

8. Burton, G.W. 1952. Quantitative inheritance in grasses. Proc. $6^{\text {th }}$ Internat. Grass land Congr. 1: 277-283.

9. Cockerham, C.C. 1963. Estimation of genetic variance. In: Hanson, W.D., and H.F. Robinson (ed.) statistical genetics and plant breeding. Publ. 982. Nat. L. Acad. Sci. Nat'l, Res. Council. Washington, D.C. p. 53-93.

10. Eberhart, S.A. 1972. Techniques and methods for more efficient population improvement in sorghum. In: N.G.P., Rao \& L.R., House (Eds.), Sorghum in Seventies. Oxford and IBH Publishing Co., New Delhi, India. pp. 197-213.

11. El-Helw.S. S. H. 2002.Genetic parameters of some economic characters in the extra-long cotton cross "Giza 68 x Sea Island" .J.Agric. Sci., Mansoura Univ., 27 (12): 2011-2020.

12. El-Lawendey, M.M.A. 2003. Effect of some selection procedures on lint yield and seed characters improvement in cotton. Ph.D. Thesis, Fac. Agric. Moshtohor Zagazig Univ., Egypt.

13. El-Lawendey, M.M., Y.M. El-Mansy and Y.A. Soliman. 2008. Multivariate analysis of economic characters in cotton (Gossypium barbadense L.). Minufiya J. Agric. Res. Vol. 33(4):955-972.

14. Falconer, D.S. 1981. Introduction to quantitative genetics $3^{\text {rd }}$ Longman, New York.U.S.A. 
15. Gooda, B.M.R. 2006. Improvement of some economic characters in crosses of Egyptian cotton (Gossypium barbadense L.). Ph.D. Thesis, Fac. Agric. Kafr ElSheikh, Tanta Univ., Egypt.

16. Johnson,V. A.,J. W. Schmidt, P. J. Matterm and A. Haunold. 1963. Agronomy and quality characteristics of high protein F2- derived families from a soft red winter wheat cross. Crop Sci.,6,7:10.

17. Mahdy,E. E., E. A. Hassaballa, M. A. Khalifa and F. G. Younis. 1987. Comparative studies on three selection procedures in an interspecific population. J. of Agric.Sci., 18(3):179-195.

18. Miller, P.A. and J.D. Rawlings. 1967. Selection for increased lint yield and correlated responses in Upland cotton, Gossypium hirsutum L. Crop Sci., 7: 637640.

19. Opondo, P. A. and R. S. Pathak. 1982. A study of heterosis and inbreeding depression for earliness and yield in Upland Cotton, Gossypium hirsutum. L.E. Afr. Agric.Forest. J.,48 (2): 25-31.

20. Richmond,T. R. 1950. Recent developments in cotton breeding. Adv. Agron. 2:63-74.

21. Shaheen, A. M. A., M. A. M. Gomaa and R. M. Esmail 2000. Response to selection for yield components and fiber properties in three Egyptian cotton crosses. Annals Agric. Sci. Ain shams Univ., 45 (2):491-506.

22. Singh, M., V.P. Singh and K. Paul. 1986. Improvement of yield and quality in upland cotton through progeny bulk selection. Indian. J. Agric. Sci., 56(8): 562566.

23. Walker, J.T. 1960. The use of selection index technique in the analysis of progeny row data, Emp. Cott. Gr. Rev. 37: 81-107. 


\section{كفاءة الاتخاب المتكرر لتحسين بعض الصفات الاقتصادية في القطن المصرى}

ياسر محمد المنسى ، ياسر عبد الرؤف محمد سليمان ، محمد عبد الفتاح ابو اليزيد

$$
\text { معهز بحوث القطن - مركز البحوث النراعبة - الجيزة - مصر }
$$

تم إجر اء دورتين من الانتخاب المتكرر في هجينين من القطن المصرى لتحسين صفة تصافى الحليج وبعض الاقتصاديه الاخرى بمحطة البحوث الزر اعية بسخا- كفر الثيخ خلال ستة مو اسم

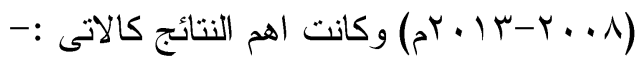

سجلت زيادة فى المتوسط من الدوره الاولى الى الــدورة الثانيــهـ مـنـ الانتخــاب المتكرر بالمقارنة بمتوسط العشيرة الاصليه.

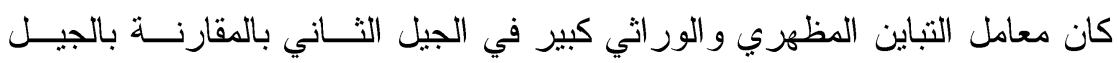

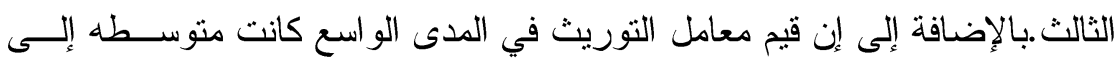
عالية لكل الصفات المدروسة في كلا العشيرتين.

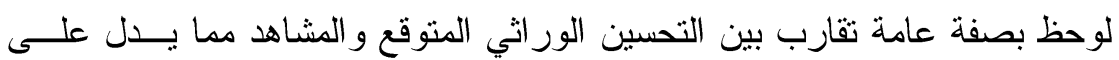

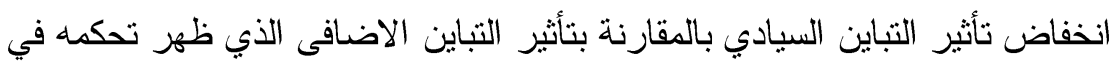
كلا العشيرتين ومن ثم يمكن للمربى الاعتماد على قيم التحسين الوراثي المتوقع.

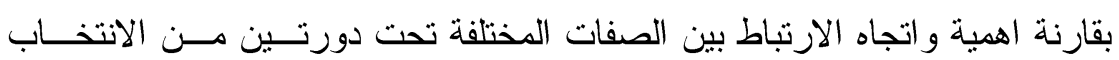

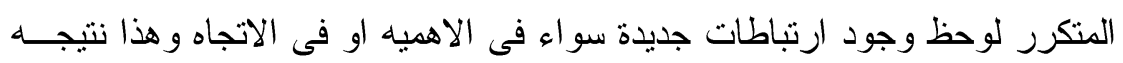

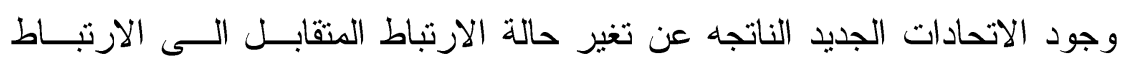
المتنافز . لوحظ زيادة تصافى الحليج في الدورة الثانية للانتخاب المتكرر عن منوسط العشيرة

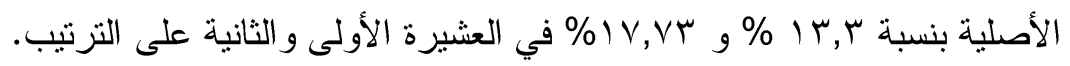

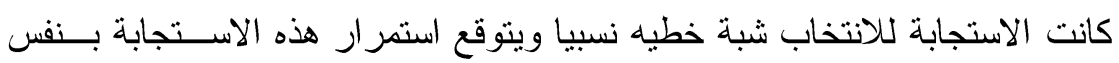

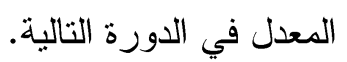

لوحظ وجود ارتباط واستجابة للانتخاب لصفة تصافى الحليج وبعض الصفات غير

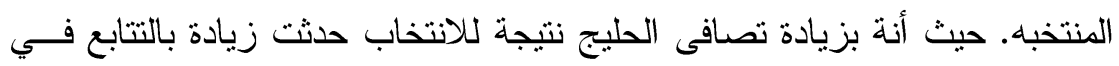

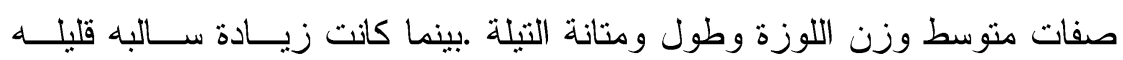

ومرغوبة لصفة نعومة التيلة.

وبالتالي يستطيع المربى الاعتماد على طريقة الانتخاب المتكرر حيث تبين إنها فعاله في

$$
\text { تحسين تصافى الحليج في القطن للحصول على عائلات متفوقة. }
$$

